\title{
Presidential Election and the Battle of Online Media Discourse in
}

\section{Indonesia}

\author{
Rudianto \\ Universitas Muhammadiyah Sumatera Utara, Indonesia \\ rudianto@umsu.ac.id
}

\begin{abstract}
In every presidential election event, the neutrality of the mass media is always a controversy. This happens in any country, including Indonesia.It is interesting to see how online mass media in Indonesia discourse political events after the 2014 presidential election. With the power of speed in presenting news, online media such as detik.com, kompas.com, vivanews.co.id are competing to present their frames on political events that took place. The focus of this article's study is on online mass media coverage of political events that occurred after the 2014 presidential election. The study was conducted with content analysis of five online media, namely detik.com, kompas.com, okezone.com and republika.co.id. The conclusion obtained is the post-2014 presidential election media discourse, especially after the voting on 9 July 2014, generally revolves around the quick count results of the survey institution's version and the winning claims of each candidate. The mass media, especially detik.com, kompas.com and vivanews.com, compile a discourse with a tendency to take sides with one of the pairs based on the results of the survey institute's quick count.
\end{abstract}

Keywords

discourse, onlinemedia; presidential election

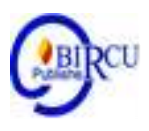

\section{Introduction}

After the voting day for the presidential election on July 9, 2014, the mass media in the country were busy providing coverage for the results of quick counts, claims for the victory of each pair and various other political events that followed. Regarding the results of the quick count, all mass media in the country reported the news quickly. Among them are online mass media which have advantages in publishing news speed. Likewise, the claim of victory between the Prabowo-Hatta and Jokowi-JK pairs made by each of the supporters received great attention from the media. This later became controversial. Many accuse the mass media of abandoning neutrality values and being dragged into the tide of supporting one partner.

In every presidential election event, the neutrality of the mass media is always a controversy. This happens in any country, including Indonesia. Since Indonesia has only implemented the Presidential Election directly since 2004, practically only three times the politics of media in the presidential election have been felt, it is no wonder that the unpreparedness of various groups for the actions of the mass media, both electronic, print and online, often creates anxiety.

In the 2014 presidential election this time, the pros and cons of the journalistic work of the mass media returned to the fore. With the two pairs of candidates, namely Prabowo-Hatta and Jokowi-Jusuf Kalla, the public quickly accused the polarization of the mass media that openly supported each pair. There are media that clearly support Prabowo-Hatta on their agenda, while others support Jokowi-JK. The media that supports Prabowo-Hatta almost every day provides space for the pair's political communication actions. This includes an agenda for 
the formation of public opinion in favor of Prabowo-Hatta. Vice versa. Television and newspapers which are known to be the supporting media for Jokowi-JK have also posted constructive news on this pair.

Political events always get attention and spotlight from the mass media including newspapers as material for coverage. Brian McNair explains:

"There are two factors that make political events become the attention of the mass media. First, today politics is in the era of mediation, namely the mass media, so it is almost impossible for political life to be separated from the mass media. In fact, political actors always try to attract journalists' attention so that their political activities get coverage from the media. Second, political events in the form of behavior and statements of political actors usually always have news value even though political events are routine in nature, for example a party meeting or a meeting of a political figure with his supporters (in Hamad, 2002: 1).

The news that is so incessant in various newspapers in Indonesia about political events cannot ignore the public as newspaper readers. In such situations, the public usually wants to know the treatment of each mass media of presidential and vice presidential candidate pairs who are involved in political events, whether proportionally or in favor of one of the parties. Especially now that the mass media plays an important role in political communication because the media are always involved in shaping political discourse. In political communication, the mass media often acts not only as a channel to convey political messages, but also as a political agent, as stated by Harsono Suwardi:

"As an agent in political communication, the media carries out a framing of political messages and this process actually causes an event or political actor to have a certain image. In the process of packaging this message, the media can choose facts which will and which are not included in the political news text". (Hamad, 2004: xvi)

If a mass media has become a political agent, the issue of objectivity in political reporting becomes a crucial issue, especially since one of the main characteristics of political news itself is the formation of public opinion. By simply becoming a political channel, the mass media can contribute to the formation of public opinion especially if they act as political agents.

In addition, according to McLuhan, in political communication, the mass media besides functioning as a tool for photographing certain events, in fact also acts as a translator who formulates, designs and formats statements about a fact (Zein, 2004: 3). The image of an event, a person, a group has actually brought new "views" to the public in interpreting the reality of an event or event.

Basically, the public only interprets the message as it is. This means that they are more influenced by the headline and issues that are highlighted than to analyze in detail the content of the news. Whereas in reality, there is often a misinterpretation of what should be conveyed and the reality that readers accept. This condition will affect public awareness and perception of political communication and the conclusions drawn.

Based on this, this article seeks to discuss how the mass media discourse after the 2014 presidential election after the voting. The main focus is on news in the national online mass media, namely detik.com, kompas.com and vivanews.co.id 


\section{Review of Literatures}

\subsection{Mass Media and Reality Construction}

The mass media actually does not present an event objectively and as it is, but rather are pieces of the incident constructed by journalists. The news that is published every day in the mass media is the result of journalists' construction of events reported through journalistic mechanisms. The reality construction process that is routine for journalists makes the media an agent in constructing the various realities that will be disseminated. The media arranges the reality of the reported events to become a story that seems to be an objective fact of the event. Therefore, what we find in the mass media in the form of news is actually not an objective reality of an event, but rather a result of the construction of reality (constructed reality). This is in line with Gaye Tuchman (in Agus Sudibyo, et.al, 2001: 65) who says that journalistic reports in the mass media are basically nothing more than the results of composing realities in the form of stories. News is basically a constructed reality.

Mass media is a tool used in conveying the message from the source to the audience by using mechanical means of communication, such as newspapers, radio, television and etc. In this case, here the mass media is print media or newspapers. According to Bitter (in Muhtadi, 1999: 73), mass media is a means of transmitting information, such as newspapers, magazines, books, films, radio and television, or a combination of shapes of media forms. Meanwhile, according to Cangara (2002: 134), mass media is a tool used in the delivery of a message from the source to the audience (receiver) using a mechanical of communication such as newspapers, radio, film and television. (Saragih, 2018)

The media has assumed more of a negative role in this negotiation process. The role of the media is important in public issues like this. The media is supposed to be informing the public about issues and interests affecting the country. During reporting the Medias are also expected to be impartial and truthful to the information they are providing to the people. Impartial and good reporting can bring transparency and accountability of the parties involved in the process. (Woldemaryam, 2020)

Meanwhile, Toni Bennet (in Eriyanto, 2002: 23). Explained that in a constructivist view, mass media is not seen as just a communication channel that functions to convey messages to audiences, but mass media is also a subject involved in the process of reality construction complete with views, biases and sides. Here the media is seen as an agent of social construction that defines reality.

Media is a tool to share or spread information or news to the people. Media is divided into two that is print media and electronic media. Print media is like news paper, magazine, etc. And electronic media is like television, radio, hand phone, internet, et cetera (Hamid in Nirawana et al, 2020)

In constructing reality, the mass media uses language as the main tool in telling reality. Language is a conceptualization and narrative tool. So important is language that there is no news, story or science without language. Peter L. Berger and Thomas Luckman in their book The Social Construction of Reality, A Treatise in the Sociology of Knowledge (1967) explain that the process of reality construction begins when a constructor objectifies a belief, namely perceptions of an object. Furthermore, the results of the meaning through the perceptual process are internalized in a constructor. It is in this stage that the conceptualization of an object that is perceived is carried out. The final step is to externalize the results of the internal reflection process through statements. The tools for making these statements are none other than words or concepts or language. (Poloma 1984: 308)

Furthermore, the use of certain languages will determine the narrative format (and meaning). Indeed, if we look closely, all content of mass media, both print and electronic 
media, must use language. The news texts that are present as a result of the journalists' construction are displayed in language so that they can be read and seen by the public. In this case, Agus Sudibyo explained that the existence of language is not only a tool to describe reality, but also can determine a picture of reality, namely media reality which will then appear in the minds of the public (Sudibyo et al 2001: 69).

Regarding reality, Peter L. Berger explained that reality is not formed scientifically, nor is it something that is revealed by God. But on the contrary it is shaped and constructed. In the perspective of social construction developed by Berger, reality is plural, dynamic and dialectical. It is not a single reality that is static and final, but rather dynamic and dialectical. This fact is plural in nature because of the social relativity of what is called knowledge and reality (Azca, 1994: 16). With this kind of understanding, reality has multiple faces.

Everyone can have a different construction of a reality. Everyone who has certain experiences, preferences, education and social or social environments will interpret these social relations with their respective constructs. the process of reality construction is basically every attempt to tell (conceptualize) an event, state or object. A journalist who reports about a presidential candidate's visit to a market is actually the journalist's attempt to construct reality. The reality can vary depending on how journalists have different views.

\subsection{Media and Political Events}

News is basically a report of events, including political events. News is obtained from the results of coverage by journalists. For the mass media, political events have always been an interesting object for reporting. The result of coverage of events carried out by journalists is called political news. Ibn Hamad explained:

"According to Brian McNair, there are two factors that make political events attractive to the mass media. First, today politics is in the era of mediation, namely the mass media, so it is almost impossible for political life to be separated from the mass media. In fact, political actors always try to attract journalists' attention so that their activities can be covered by the mass media. Second, political events in the form of behavior and statements of actors usually always have news value even though the political events are of a routine nature, for example a party meeting or a meeting of political figures with their supporters ". (Hamad, 2004: 1).

Although all the events that occur can be used as material for coverage to be produced into news, the process of covering political events tends to be more complicated than other events. This is because political coverage has a dimension of shaping public opinion, both what journalists and politicians expect. In political communication, the aspect of opinion formation is indeed the main goal, because it will affect the political achievements of political actors.

Brian McNair further stated:

"In forming public opinion, the mass media generally carries out three activities at once. First, using political symbols. Second, carry out framing strategies. Third, perform the function of the media agenda (agenda setting function)"(in Hamad, 2004: 2).

When carrying out these three actions, the mass media may be influenced by various factors in the form of certain editorial policies regarding a political activity, political interests of media managers, media relations with a certain political force and external factors such as market pressure for readers or viewers, the prevailing political system. and other outside forces. Thus, one political event may lead to different public opinion depending on the way each media carries out these three actions.

On the other hand, today's mass media activities, including in Indonesia, have become an industry. With the inclusion of the capital element in the media business, it is inevitable that 
media workers have to think about how to get profits from both sales and advertising. All of that will affect the reality construction carried out by journalists in seeing a political reality. For this reason, although the mass media often claim that they always try to be neutral, in covering political events, such a neutral attitude is unlikely.

Ibnu Hamad in his research entitled Construction of Political Reality in Mass Media (2004) argues that there are three actions that are commonly carried out by media workers, especially mass communicators, when constructing political reality which leads to the formation of an image of a political force: the selection of symbols (language function); selection of facts to be presented (framing strategy) and willingness to give space (agenda setting). (Hamad, 2004: 16).

\subsection{Production News}

News is produced through a journalistic process that involves journalists. The earliest stage for producing news is how journalists perceive the events they are witnessing. News is the end result of a complex process of sorting and defining events and specific themes. As MacDougall says:

"Every day there are millions of events in this world that have the potential to make news. These events do not automatically become news because of the limits provided and calculated, which ones are news and which are not news. News therefore, events that have been determined as news are not events in themselves". (Eriyanto, 2002: 102).

In Fishman's view (in Eriyanto, 2002: 100) there are two trends in how the news production process is viewed. The first view is often called the news selection view. In essence, the news production process is a selection process. Selection is carried out by journalists who choose which events are important and which are not. The second view is the news formation approach. In this view, the news is not selected but formed. Journalists form it, which news is called which is not.

In carrying out the news production process, there are several factors that become important concerns, namely organizational routines, news values, categorization and professional ideology (Hall in Eriyanto, 2002:).

Meanwhile, Shoemaker and Reese (1991: 90) mention some news values, namely:

1. Prominance / Important. Events that are considered important because of the size of the event.

2. Human interest. Events that contain elements of emotion, sadness, joy, and emotion.

3. Conflict / controversy. Events that contain elements of conflict, violence and conflict.

4. The Unusual. Extraordinary and rare events.

5. Proximinity. Events that are physically and emotionally close to audiences.

Through a journalistic process, the news is then displayed in the form of news text. In producing news texts, journalists are influenced by many things. Shoemaker and Reese (1991: 117) say that news texts produced by the mass media are influenced by individual media workers, media routines, media organizations themselves, institutions outside the media and ideology. The influence of these factors is in a hierarchical relationship. The individual factors of media workers influence the text in the functions determined by the routines of the media. The functions performed routinely must fall within the functions defined by the media organization. Likewise, the policies taken by media organizations are largely determined by institutions outside the media. And at the very top, whether we realize it or not. 


\section{Research Methods}

This research was conducted using Halladay's discourse analysis method. This method is a qualitative content analysis method. Halladay's method of discourse analysis includes three elements, namely the field of discourse, namely social action that is currently taking place or being discussed, the tenor of discourse, namely the parties involved in the discussion and the mode of discourse, namely the choice of language. each media (in Kriyantono 2008: 261).

Analysis was carried out on news in the country's online mass media, namely detik.com, kompas.com and vivanews.com. These three media were chosen because they are one of the largest online media. When viewed from their followers on social media, twitter detik.com has more than 9.6 million followers. Kompas.com 3.4 million followers and vivanews.com which has 2.4 million followers. In addition, these three media are seen as having an influence on the formation of public opinion and agenda through their reporting in the community.

The news that is observed is news published after the voting day for the 2014 presidential election. At this time, political events are tinged with debates about the results of quick counts conducted by survey institutions which are then published by the mass media.

\section{Result and Discussion}

\subsection{Discourse Kompas.com}

Kompas.com is an online news site belonging to the Kompas Gramedia group. Even though the name is the same as the Kompas Daily, the contents of kompas.com are not the same as the printed version. For the printed version, Kompas has a Kompas Daily with an online addresswww.print.kompas.com. Kompas.com is one of the largest online news sites in Indonesia. At least when viewed from his followers on social media, Twitter is over 3 million. Kompas.com is also an online medium that is fast in updating the latest news.

After the election for the 2014 presidential election, to be precise on July 9, 2014, kompas.com published news about the voting situation throughout the country. After 3:00 p.m., which was the time limit allowed by the KPU for survey agencies to start releasing the quick count results, kompas.com immediately stepped on the gas. One of the stories that stood out was the one with the headline "quick count". These are the complete results of the 11 survey institutions ". This news was published at 18.00. The news tells about the complete results of the quick count conducted by 11 survey institutions, namely the Indonesian Survey Circle, Indonesian Political Indicators, the Populi Center, CSIS, Radio Republik Indonesia, and the Saiful Mujani Research Center. Puskaptis, Indonesia Research Center, National Survey Institute, and Indonesian Voice Network.

From the discourse field element, the above news raises the topic of the final results of the survey institutions' version of the quick calculation. Kompas.com emphasized that there were significant differences in seven of the eleven survey institutions regarding the candidate pairs that were claimed to have won the quick count version of the presidential election. On news leads, kompas.com wrote:

"Seven of the 11 survey institutions that carried out quick counts in the 2014 presidential election named Joko Widodo and Jusuf Kalla as the winner of the vote".

Kompas.com mentions seven survey institutions, namely the Indonesian Survey Circle, Indonesian Political Indicators, Populi Center, CSIS, Radio Republik Indonesia, and Saiful Mujani Research Center as institutions that declared the victory of Jokowi-JK. Meanwhile, four institutions, namely Puskaptis, Indonesia Research Center, National Survey Institute, and Indonesian Voice Network as institutions that declared Prabowo-Hatta as the winner. 
The online media kompas.com also placed stories about each candidate pair claiming victory on the basis of quick calculations. Prabowo-Hatta is described as making a prostration of gratitude as a claim of victory. Meanwhile, Jokowi-JK celebrated the claim of victory with their supporters at the Proclamation monument.

From the elements of discourse involvement, kompas.com did not use sources but instead put the names of 11 survey institutions in their respective positions in the quick calculation results. Placing the seven survey institutions that won Jokow-JK compared to the four survey institutions that won Prabowo-Hatta is kompas.com's strategy in compiling facts. Plus the names of survey institutions that won Jokowi-JK such as the Indonesian Survey Circle, Indonesian Political Indicators, Populi Center, CSIS, Radio Republik Indonesia, and Saiful Mujani Research Center which has been a popular survey institution.

The discourse mode compiled by kompas.com is to use an explanatory language style. By comparing seven and four survey institutions, kompas.com would like to emphasize based on the data and figures it has obtained that the victory belongs to Jokowi-JK.

\subsection{Discourse Vivanews.co.id}

Viva.co.id or Vivanews is a national online news site under the Viva group. It is widely known that Viva is a media business group whose shares are owned by Golkar Chairman Aburizal Bakrie. Apart from owning Viva, Ical also manages news television TV One and AnTV. Viva is one of the largest online media in Indonesia. Judging from his followers on twitter, Vivanews currently has more than 2 million followers. In terms of updating news, Vivanews is fairly fast in updating the latest news.

Like kompas.com, Vivanews also covered news about the voting atmosphere in the country on July 9, 2014. After 15.00 WIB, this media began releasing news on the results of quick counts up to the candidates' claim of victory.

At 16.04 WIB, Vivanews released the news "Prabowo: Survey Shows Prabowo-Hatta Wins". The discourse field compiled by Vivanews is about the Presidential Candidate's statement carried by Gerindra, the Golkar Party, PAN, PKS and PPP, namely Prabowo Subianto and Hatta Rajasa responding to the survey institute's version of the quick count. By directly involving Prabowo as a presidential candidate, Vivanews published the version of the winning claim by three survey agencies that did quick counts. Although the names of the survey agencies were not mentioned. Only in the middle of the news did Vivanews attach a news link with the title "10 Lambaga Survey Quick Count Results" which readers could refer to if they wanted to see the details of the quick count results.

Regarding the victory celebration, Vivanews wrote Prabowo's statement that he did not want to rush to declare a victory until 100 percent of the data entered. Vivanews uses descriptive discourse mode in writing news taken from the Prabowo-Hatta press conference at Polonia's house, the headquarters of their winning team.

\subsection{Discourse detik.com}

Detik.com is arguably the largest news site in Indonesia. When viewed from the Alexa.com version of the web ranking, detik.com is ranked 384 in the world and no. 7 most popular in Indonesia. In the twitter universe, the media which is now owned by Chairul Tanjung's Transcorp group has more than 9 million followers.

Detik.com is very updated in monitoring the progress of the implementation of voting on the July 92014 election. Including news about quick counts. With its short spot news style, detik.com wrote all the quick count results belonging to the survey institutions that won Prabowo-Hatta or Jokowi-JK. 
In the midst of the busy news about the quick count claimed by each candidate, at 20.04 WIB detik.com released a news titled "Jokowi: We Are the Benchmark for a Credible Survey Institute". The lead appointed by detik.com "There was something interesting after the 2014 presidential election voting. When one by one the quick count institutions released the survey results. As a result, Jokowi-JK excelled in most of the surveys, while the Prabowo-Hatta camp claimed victory as well "showing the field of discourse being discussed, namely debates and claims of candidate victories related to quick count results..

Detik.com directly used Jokowi as a discourse actor. Apart from that detik.com wrote down the names of survey institutions which Jokowi said were credible, namely Saiful Mujani Research Center (SMRC), Kompas Research and Development,RRI, Political Indicators and ISI. It is known that these institutions in their quick count declared the victory of Jokowi-JK, in contrast to several institutions that declared Prabowo-Hatta's victory. Detik.com also builds discourse through discourse mode with descriptive language to convince readers that the victory belongs to Jokowi-JK. At $22.57 \mathrm{WIB}$, for example, detik.com released the news "If officially becoming president, where will Jokowi stay". Jokowi was involved in the discourse of the lead that was appointed "Candidate number two, Joko Widodo (Jokowi) excelled in the 2014 presidential election quick count by several survey institutions. Then, if he becomes President, where will Jokowi live? " illustrates the belief that Jokowi-JK will win the 2014 presidential election.

Based on the analysis above, it can be seen that after the voting on July 9, 2014, the media in the country, especially online media detik.com, kompas.com and vivanews.com, were fighting each other through the news. The very prominent discourse, especially on July 9, 2014 after the voting was over, was about the results of the survey institute's version of the quick count. The media discussed the position of the survey institute's version of the quick count which is very important for all the public to know regarding the results of the presidential election.

In addition, the three media also build their respective discourses based on the elements of the discourse field, discourse actors and discourse modes that lead to the victory of one of the partners. Even though in terms of providing coverage, it seems balanced, from the structure of the discourse that was built, it is undeniable that detik.com and kompas.com tend to try to convince readers that based on the quick count results, Jokowi-JK is the winner of the 2014 presidential election. The discourse that he developed cannot be separated from the tendency that Prabowo-Hatta, based on several survey institutions, won the 2014 presidential election, at least from a quick count.

This is in line with what was stated by Toni Bennet (in Eriyanto, 2002: 23). that in a constructivist view, mass media is not seen as just a communication channel that functions to convey messages to audiences, but mass media is also a subject involved in the process of reality construction complete with its views, biases and sides.

\section{Conclusion}

1. The media discourse after the 2014 presidential election, especially after the voting on July 9,2014 , generally revolved around the results of the survey institutions' quick counts.

2. The mass media, especially detik.com, kompas.com and vivanews.com, compile a discourse with a tendency to be partial or biased towards one of the pairs based on the results of the survey institute's quick count.

3. The three media analyzed, namely kompas.com, detik.con and vivanews.com were fighting against each other over the claim of victory through the survey institute's version of the quick count. 
4. The media discussed the position of the survey institute's version of the quick count which is very important for all the public to know regarding the results of the presidential election. In addition, the three media also build their respective discourses based on the elements of the discourse field, discourse actors and discourse modes that lead to the victory of one of the partners.

\section{References}

Eriyanto. (2001). Analisis Wacana: Pengantar Analisis Teks Media. Yogyakarta: LKIS

-------. (2002). Analisis Framing. Konstruksi, Ideologi dan Politik Media. Yogyakarta: LKIS.

Hamad, Ibnu. (2004). Konstruksi Realitas Politik dalam Media massa: Sebuah Studi CDA terhadap berita-berita Politik. Jakarta: Granit

Kriyantono, Rachmat. (2008). Teknik Praktis Riset Komunikasi: Disertai Contoh Praktis Riset Media, Public Relations, Advertising, Komunikasi Organisasi, Komunikasi Pemasaran. Jakarta: Kencana Prenada Media Group.

McQuail, Denis. (1987). Teori Komunikasi Massa; Suatu Pengandar. Edisi Kedua. Jakarta. Erlangga

Nimmo, Dan. (2000). Komunikasi Politik:Komunikator, Pesan dan Media. Bandung. Remaja Rosdakarya

Nirwana, A. et al. (2020). The Media of Washatiyah Dakwah in Quranic Exegesis Study. Budapest International Research and Critics Institute-Journal (BIRCI-Journal). P. 911922.

Paloma M, Margaret. (2000). Sosiologi Kontemporer. Jakarta:PT Raja GGGrafindo Persada

Sobur, Alex. (2002). Analisis Teks Media: Suatu Pengantar untuk Analisis Wacana, Analisis Semiotik dan Analisis Framing. Bandung. Remaja Rosdakarya

Saragih, M. (2018). Some Characteristics of Islamic Journalism Based on Al Quran. Budapest International Research and Critics Institute-Journal (BIRCI-Journal). P. 01-10

Shoemaker, Pamela J and Reese, Stephen D. (1991). Mediating the Message.: Theories on influences on Mass Media Content. New York.Longman

Suwardi, Harsono. (1993). Peranan Pers dalam Politik di Indonesia. Jakarta. Sinar Harapan.

Woldemaryam, E. (2020). Making the Nile River a Point of Cooperation between Ethiopia and Egypt: Building Confidence through Water Diplomacy. Budapest International Research and Critics Institute-Journal (BIRCI-Journal). P. 2494-2500

Zen, Fathurin. (2004). NU Politik: Analisis Wacana Media. Yogyakarta: LKIS. 